\title{
Notes on Books
}

The Diabetic Life-Its Control by Diet and Insulin. By R. D. Lawrence, M.A., M.D., M.R.C.P. Fifth Edition. London: J. \& A. Churchill. I930. Price 8s. 6d.

Uniform with the Recent Advance Series, this little volume appears to have attained the same popularity enjoyed by them. The book aims at bringing the modern treatment of diabetes within the scope of the general practitioner and the understanding of the patient. It describes in detail the various difficulties likely to be encountered, and the methods of dealing with them. The deservedly popular "Line Diets" system introduced by the author is admirably set forth and is illustrated by numerous examples. This is really one of the most practical and useful of the many books on this subject, and we have no hesitation in thoroughly recommending it.

\section{NOTES ON BOOKS}

Ultra-Violet Rays in the Treatment and Cure of Disease, by Percy Hall, M.R.C.S. (Eng.), L.R.C.P. (Lond.), (Heinemann (Ltd.), i 2s. 6d.). That a fourth edition has been called for five years after publication is proof that this work is to be relied upon as a guide to the increasing number of practitioners interested in actino-therapy. In reading of the cases quoted by the author one is struck by the small and infrequent dosage found to be effective; this gives food for thought. New chapters on self-administration and on dosage add value to a book which can be highly recommended.

Comment Rajeunir, by Hélan Jaworski. Pp. 248 (Paris: Albin Michel, I 2 francs). An attractively presented account of the author's method of rejuvenation by means of the injection into the old of the serum of the young. Detailed accounts are given of the effect of this treatment in cases of animals and man. The book is no less remarkable for its literary style than for the ingenuity of its argument and of the techniques discussed.

Testicular Grafting from Ape to Man, by Serge Voronoff and George Alexandrescu. Translated by Theodore C. Merrill, M.D. (Brentano's Ltd.). This small publication includes details of further facts and information which have accumulated since the appearance of The Study of Old Age and My Method of Rejuvenation. It gives an account of the technique employed in testicular grafting, the steps 


\section{Notes on Books}

of the operation being illustrated by means of very clear figures, an account of the physiological phenomena observed subsequent to the operation, of sections of the testicular grafts removed after various periods of time, an account of the histological changes in the grafts, and finally a statistical summary of 475 cases of simian testicular grafting upon man which have been carried out in cases of premature senility with 90 per cent. of success; senility with 74 per cent.; prostatitis with 82 per cent.; obesity, 84 per cent.; diabetes, 67 per cent.; impotence following orchitis, 57 per cent.; impotence following onanism, 89 per cent.; sexual inversion, 57 per cent.; infantilism, $5^{6}$ per cent.; anorchidia, 22 per cent. Histologists will disagree amongst themselves concerning the degree of degeneration found in the testicular grafts and the physiological effects that it is stated have followed upon testicular implantation.

The Writing of Medical Papers, by Mrs Mellish-Wilson, has reached a third edition (Saunders, $7 \mathrm{~s}$. 6d.). It contains admirable instructions for young writers which, if followed, would diminish the work of editors and make for the comfort of readers. A useful section is the standard abbreviations for tables of Medical Journals, which runs to 47 pages.

International Health Year-Book, 1928, League of Nations (Constable, 20 francs). This is the fourth of a series of annual publications dealing with organisation and results of the public health services of twenty-nine countries. Each country is responsible for the summary of its own activity in "all branches of public health endeavour," and this volume is in the nature of a progress report on all important advances during the year under review. Information regarding a wide range of general demographic, vital and public health statistics is embodied in twenty-eight standard tables designed to present "the minimum of vital statistics necessary for correct interpretation of the information relating to the health conditions in the country under consideration." Useful items included are the details of Health Insurance and public health budgets. This compendium becomes more valuable with each year's publication.

Hypochondria, by R. D. Gillespie, M.D., M.R.C.P., D.P.M. (Kegan Paul, 2s. 6d.). An excellent little book, in which the historical views about hypochondria are surveyed and its nature is discussed from a modern standpoint. Emphasis is laid upon the delimitation of hypochondria as a nosological entity distinct from melancholia, hysteria and neurasthenia. The discussion of its psychopathology is inconclusive, but the psycho-analytic interpretation receives most attention. 


\section{Notes}

Urological Nursing, by David M. Davis, M.D. (Saunders, ros. 6d.), should greatly help nurses or dressers attached to a charge where much urological work is done. The first three chapters are devoted to anatomy; physiology and pathology. Thereafter the special bedside duties of the nurse are summarised. A full descriptive list of instruments and appliances is detailed, methods of sterilisation and indications for use being clearly and concisely stated.

\section{NOTES}

A Quarterly Meeting of the Royal College of Physicians was held on Royal College of Tuesday, 6th May 1930. The President, Sir Physicians Norman Walker, was in the Chair. Drs James Edinburgh. Kirkwood Slater (Edinburgh), John Henry Douglas Webster (London) and Sydney Watson Smith (Bournemouth) were introduced and took their seats as Fellows of the College. Lt.-Col. William Frederick Harvey, C.I.E. (Edinburgh) and Dr Herman Petrus Gunnar (Illinois) were elected Fellows of the College.

Dr John Orr was elected a Representative of the College on the Committee of Management of the Triple Qualification. The Parkin Prize was awarded to Dr R. J. S. McDowall, F.R.C.P. (London).

The award of the Lister Fellowship was divided equally between Drs Ralph Stockman Begbie and Donald Stewart. Dr W. A. Alexander, F.R.C.P., was granted Recognition as a Lecturer on the Practice of Physic.

The College decided to celebrate the 250 th Anniversary of its Foundation on St Andrew's Day, I93I.

Intimation was made of a Bequest by Mrs Isabella Kirk Duncanson for the Foundation of a Fellowship in Medical Research.

At the recent examination of the Royal College of Physicians of Triple Qualification Edinburgh, the Royal College of Surgeons of EdinDiploma in Public burgh and the Royal Faculty of Physicians and Health.

Surgeons of Glasgow, held at Edinburgh, the following candidates having passed the requisite examinations were admitted Diplomates in Public Health:-Arnold A. Hamilton, M.D., S. S. Misra, M.B., B.S., Christopher W. Clayson, M.B., Ch.B., H. C. Mehta, M.B., B.S., William A. M'E. Stewart, L.R.C.P. \& S. Edin., James L. Chisholm, M.D., M.R.C.P.E., Donald A. Fraser, M.B., Ch.B. 